\title{
Influence of dietary linseed oil and sunflower seed oil on some mechanical and metabolic parameters of isolated working rat hearts
}

\author{
L Demaison *, A Grynberg \\ INRA, Station de Recherches sur la Qualité des Aliments de l'Hormme, \\ Unité de Nutrition Lipidique, 17 rue Sully, BV 154021034 Dijon Cedex, France
}

(Received 28 February 1990; accepted 12 November 1990)

\begin{abstract}
Summary - The role played by membrane lipid environment on cardiac function remains poorly defined. The polyunsaturated fatty acid profile of myocardial phospholipids could be of utmost importance in the regulation of key-enzyme activities. This study was undertaken to determine whether selective incorporation of $n-6$ or $n-3$ fatty acids in membrane phospholipids might influence cardiac mechanical performances and metabolism. For $8 \mathrm{wk}$, male weanling Wistar rats were fed a semipurified diet containing either $10 \%$ sunflower seed oil $(72 \%$ C18:2 $n-6)$ or $10 \%$ linseed oil $(54 \%$ C18:3n-3) as the sole source of lipids. The hearts were then removed and perfused according to working mode with a Krebs-Henseleit buffer containing glucose $(11 \mathrm{mM})$ and insulin (10 UI/I). Cardiac rate, coronary and aortic flows and ejection fraction were monitored after 30 min of perfusion. Myocardial metabolism was estimated by evaluating the intracellular fate of $1-14 \mathrm{C}$ palmitate. Sunflower seed oil and linseed oil feeding did not modify either coronary or aortic flow, which suggests that cardiac mechanical work was not affected by the diets. Conversely, cardiac rate was significantly decreased $(-18 \% ; P<0.01)$ when rats were fed the $n-3$ polyunsaturated fatty acid rich diet. Radioanalysis of the myocardial metabolism suggested that replacing $n-6$ polyunsaturated fatty acids by $n-3$ polyunsaturated fatty acids: i) did not alter palmitate uptake; ii) prolonged palmitate incorporation into cardiac triglycerides; iii) reduced beta-oxidation of palmitic acid. These results support the assumption that dietary fatty acids, particularly $n-6$ and $n-3$ fatty acids, play an important role in the regulation of cardiac mechanical and metabolic activity.
\end{abstract}

dietary polyunsaturated fatty acid / membrane phospholipid / isolated perfused rat heart / mechanical activity / metabolism

Résumé - Influence de l'apport alimentaire en huile de lin ou en huile de tournesol sur quelques paramètres mécaniques et métaboliques du cceur isolé et perfusé de rat. Le rôle joué par l'environnement lipidique membranaire sur la fonction du myocarde reste mal défini. Le profil en acides gras polyinsaturés des phospholipides cardiaques pourrait avoir une influence considérable sur la régulation de certaines enzymes clés. Cette étude a été réalisée pour savoir si une incorporation sélective d'acides gras n-6 ou n-3 dans les phospholipides membranaires peut provoquer des modifications des activités mécanique et métabolique du cceur. Des rats mâles de souche Wistar

\footnotetext{
* Correspondence and reprints.
} 
pris au sevrage ont été nourris avec un régime semi-liquide contenant soit 10\% d'huile de tourneseol, soit $10 \%$ d'huile de lin. Après 8 semaines de régime, les cceurs ont été prélevés puis perfusés en mode travaillant avec un liquide physiologique contenant du glucose (11 mM) et de l'insuline (10 UIII). La fréquence cardiaque, les débits coronaire et aortique et le volume d'ejection systolique ont été évalués après 30 min de perfusion. Le métabolisme myocardique a été déterminé en suivant le devenir intracellulaire de l'acide palmitique $1-14 \mathrm{C}$. L'absorption d'huile de lin ou de tournesol n'a modifié ni le débit coronaire, ni le débit aortique, ce qui suggère que le travail mécanique du myocarde n'a été modifié par aucun des 2 régimes. En revanche, la fréquence cardiaque a été légèrement diminuée $(-18 \% ; \mathrm{P}<0.001)$ chez les animaux recevant l'huile de lin dans le régime. La radioanalyse du métabolisme cardiaque suggère que l'huile de lin :

- ne modifie pas le captage myocardique du palmitate;

- prolonge l'incorporation du palmitate marqué dans les triglycérides cardiaques;

- réduit la bêta-oxydation de l'acide gras radioactif. Ces constatations suggèrent que les acides gras alimentaires, particulièrement les acides gras polyinsaturés de la série n-3 et $n-6$, jouent un rôle important dans la régulation du métabolisme et de la contractilité cardiaque.

acide gras polyinsaturé alimentaire / phospholipide membranaire / ccur isolé et perfusé de rat / actlvité mécanique / métabolisme

\section{INTRODUCTION}

It is now clearly established that the fatty acid profile of cardiac phospholipids depends largely on the dietary fatty acid intake. The $n-3$ polyunsaturated fatty acid rich oils such as fish oil or linseed oil are responsible for a decrease in the $n-6 / n-3$ ratio in cardiac phospholipids (Rocquelin et al, 1986; Swanson et al, 1986; Hartog et al, 1987; Nalbone et al, 1988). On the other hand, these changes in cellular lipid environment may induce noticeable alterations in cardiac function (Hock et al, 1987; Grynberg et al, 1988; Lamers et al, 1988) by modulating the activity of membranebound enzymes. Nevertheless, the relationship between membrane composition and myocardial activities remains poorly defined. Several biological models including membrane preparations, isolated organelles such as mitochondria, cultured cardiomyocytes, isolated perfused hearts and in vivo conditions are available to study the influence of dietary fatty acids on cellular function. Amongst these models, the working perfused rat heart offers several opportunities such as the determination of mechanical work, the suppression of humoral and central nervous regulation and the determination of some biochemical and mechanical parameters which have hardly been assessed in vivo. The purpose of the present study was to evaluate the influence of dietary n-6 or $n-3$ polyunsaturated fatty acids on the mechanical function and the metabolism of working perfused rat hearts. The metabolic function was investigated by following the intracellular fate of radiolabelled palmitate.

\section{MATERIALS AND METHODS}

\section{Animals, diets and feeding procedure}

Eighty weanling male Wistar rats were housed in individual cages in temperature-controlled animal quarters and randomly assigned to 2 groups. For 8 wk the animals were fed ad libitum a semi-purified diet containing casein $(18 \%)$, starch $(39.5 \%)$, sucrose $(26.5 \%)$, a salt 
mixture $(4 \%)$, agar agar $(2 \%)$, vegetable oil $(10 \%)$ and a vitamin mixture. Only the oil fraction in the 2 groups differed: $10 \%$ sunflower oil in group $\mathrm{S}$, and $10 \%$ linseed oil in group $\mathrm{L}$. The fatty acid composition of the oils used is presented in table $\mathbf{I}$.

\section{Fatty acid composition of the hearts}

The hearts were excised $(n=6)$ and the lipids extracted according to Folch et al (1957). Phospholipids were isolated using a Sep-pack cartridge (Juaneda and Rocquelin, 1985). The fatty acids were transmethylated with $B F 3 /$ methanol and analyzed by gas chromatography on a Carbowax $20 \mathrm{M}$-AT column.

\section{Perfusion procedure}

The animals were anesthetized with diethylic ether vapors and heparinized via the saphenous vein ( $\approx 500$ IU heparin, Sigma Chemical). After rapid thoracotomy, the hearts were quickly removed and immersed in a $4^{\circ} \mathrm{C}$ Krebs-Henseleit solution until they stopped beating. They were then perfused at $37^{\circ} \mathrm{C}$ via the aorta according to the Langendorff procedure with a KrebsHenseleit medium containing glucose (11 $\mathrm{mM}$ ) and insulin $(10 \mathrm{UI} / \mathrm{l})$. To provide the hearts with enough oxygen and to maintain the extracellular pH at 7.4, the Krebs-Henseleit medium was con-

Table I. Fatty acid composition (\%) of dietary oils.

\begin{tabular}{|c|c|c|c|}
\hline \multicolumn{2}{|c|}{ Fatty acids } & Sunflower & Linseed \\
\hline $16: 0$ & & 5.0 & 4.0 \\
\hline 18:0 & & 5.5 & 4.0 \\
\hline $18: 1$ & $n-9$ & 15.5 & 19.0 \\
\hline $18: 1$ & $n-7$ & 0.5 & 1.0 \\
\hline $18: 2$ & $n-6$ & 71.5 & 17.5 \\
\hline $18: 3$ & $n-3$ & 0.2 & 53.5 \\
\hline $20: 0$ & & 0.3 & 0.5 \\
\hline $20: 1$ & $n-9$ & 0.2 & 0.3 \\
\hline $22: 0$ & & 1.0 & 0.2 \\
\hline
\end{tabular}

tinuously bubbled with carbogen ( $95 \%$ oxygen $5 \%$ carbon dioxide). During this period, the left atrium was cannulated and after 15 min of Langendorff perfusion, the hearts were perfused according to working mode (Neely et al, 1967). The water level difference between the atrial cannula and the preload chamber was adjusted to $15 \mathrm{~cm}$. However, the carbogen pressure in the preload chamber was elevated but constant, suggesting that the preload pressure was more elevated than $15 \mathrm{~cm}$ water. A direct measurement of the preload pressure was not performed. The postload was settled to a waterlevel of $65 \mathrm{~cm}$. The working heart perfusion was maintained for 15 min before intracoronary injection of a bolus of $1-14 \mathrm{C}$ palmitate $(0.6 \mathrm{ml}$, specific activity $=1554 \mathrm{MBq} / \mathrm{mM}$ ) via the atrial cannula. The perfusion with non-labelled KrebsHenseleit buffer was maintained for $1,2.5$ or 5 $\mathrm{min}$ and the hearts frozen in liquid nitrogen and stored at $-80^{\circ} \mathrm{C}$ until biochemical analyses were carried out. During the working heart perfusion period, the aortic pressure was continuously recorded by means of a pressure gauge located at the top of the aortic cannula. However, a direct measurement of the aortic pressure was not obtained. Furthermore, the coronary and aortic flows were determined every $5 \mathrm{~min}$ throughout perfusion.

\section{Biochemical analysis}

The technique of Bligh and Dyer (1959) was used for cardiac lipid extraction. Briefly, the ventricles were ground in a mortar in liquid nitrogen. Fifteen $\mathrm{ml}$ of chloroform-methanol-water 20:10:8 (v/v) were added to the powdered myocardium. After homogenization with a polytron $\left(4^{\circ} \mathrm{C}, 30 \mathrm{~s}\right), 2 \mathrm{ml}$ of chloroform and $1 \mathrm{ml}$ of water were added. This operation was followed by a second homogenization $(30 \mathrm{~s})$ and $5 \mathrm{ml}$ of chloroform were then added to the homogenate. Lipid extraction was completed by a third homogenization ( $30 \mathrm{~s}$ ). Radioactivity in the aqueous and lipid phases was determined with a liquid scintigraphy counter (2 000 CA Packard). Separation of the different classes of cardiac lipids was carried out by thin-layer chromatography according to Bizerte et al (1964). Separation of the lipid classes was performed on silica gel layers (Kieselgel 60F254, Merck) using a petroleum ether-diethyl ether-acetic acid mixture 
$(85: 15: 2 \mathrm{v} / \mathrm{v})$ as a solvent system. Polar lipid, free fatty acids, diglyceride and triglyceridepeaks were identified with pure standards. The distribution of radioactivity in the different lipid classes was determined with a radiochromatograph (Berthold).

\section{Statistical analysis}

The results are reported as mean \pm SEM (standard error of the mean). The mechanical parameters were submitted to a 1-way analysis of variance. For the biochemical parameters, a 2-way analysis of variance (time and diet) was carried out (Dagnelie, 1975). The results thus concern the oil effect (Oef), the time effect (Tef) and the cross-interaction $(\mathrm{Cl})$ of these 2 factors, which indicates a difference in the time evolution of the 2 groups.

\section{RESULTS}

The fatty acid composition of the phospholipids is shown in table II. The differences

Table II. Fatty acid composition (\%) of total heart phospholipids.

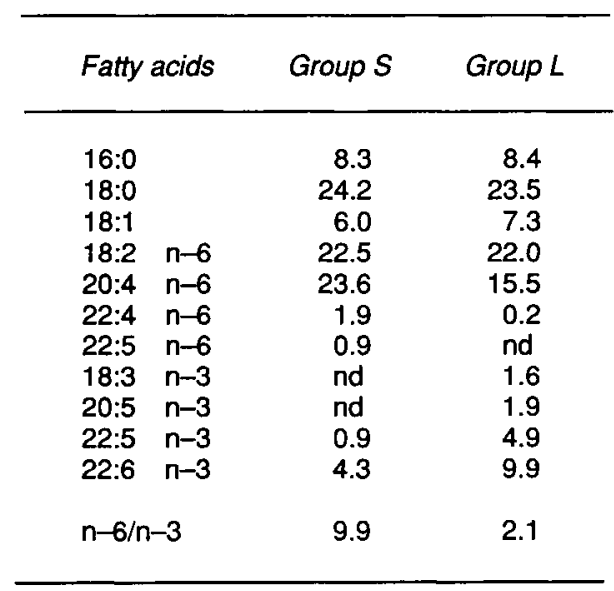

nd $=$ not detected. can be seen in the $n-6 / n-3$ ratio which varies from $\approx 10$ in groups $S$ to 2 in group $L$.

\section{Mechanical function}

The influence of dietary fatty acids on cardiac performance and hemodynamics is presented in table III. The diet did not significantly affect either the coronary or the aortic flow which suggests that myocardial work was similar, but influenced cardiac rate, suggesting that $n-6$ PUFA-enriched hearts required more beats to maintain a similar intensity of mechanical work. Of course, systolic ejection volumes behaved inversely as compared to cardiac rates and were lower in group $S$ than in group $L$ $(-15 \%, P<0.05)$. Thus, although cardiac rate and ejection fractions were different in both experimental groups, the mechanical work did not seem to be altered, which allowed comparison of the metabolic parameters.

Table III. Effect of sunflower seed oil and linseed oil intake on coronary and aortic flow, spontaneous beating and systolic ejection volume of isolated perfused rat hearts (means \pm SEM).

\begin{tabular}{|c|c|c|c|c|}
\hline Group & $\begin{array}{c}\text { Coronary } \\
\text { flow } \\
\text { (ml/min) }\end{array}$ & $\begin{array}{c}\text { Aortic } \\
\text { flow } \\
(\mathrm{m} / \mathrm{min})\end{array}$ & $\begin{array}{c}\text { Cardiac } \\
\text { rate } \\
\text { (beat/min) }\end{array}$ & $\begin{array}{c}\text { Ejection } \\
\text { volume } \\
\text { (m/seat) }\end{array}$ \\
\hline$\underset{(n=20)}{S}$ & $\begin{array}{r}17.7 \\
\pm 1.3\end{array}$ & $\begin{array}{r}48.2 \\
\pm 2.2\end{array}$ & $\begin{array}{l}230.0 \\
\pm 5.5\end{array}$ & $\begin{array}{r}0.213 \\
\pm 0.012\end{array}$ \\
\hline$\stackrel{\mathrm{L}}{\mathrm{L}}$ & $\begin{array}{r}18.5 \\
\pm 0.9\end{array}$ & $\begin{array}{r}45.8 \\
\pm 2.1\end{array}$ & $\begin{array}{l}189.0 \\
\pm 8.3\end{array}$ & $\begin{array}{r}0.250 \\
\pm 0.013\end{array}$ \\
\hline ANOVA & A NS & NS & $P<0.001$ & $P<0.05$ \\
\hline
\end{tabular}

ANOVA $=$ analysis of variance; $N S=$ not significant. 


\section{Metabolic function}

The fatty acid metabolism was investigated after intracoronary injection of a bolus of $1-14 \mathrm{C}$ palmitate. The intracellular fate of the labelled fatty acid was estimated by evaluating the radioactivity in different cellular biochemical compartments. The total radioactivity (fig 1) was similar at $1 \mathrm{~min}$ post-injection (pi) in $n-6$ and n-3 PUFArich hearts and then decreased with time, indicating a similar uptake of $1-14 \mathrm{C}$ palmitate. As attested by the significant $F$ value of diet-time cross-interaction, cardiac radioactivities followed a different evolution with time: in rats fed linseed oil, the decrease in total radioactivity was weak between the first and the fifth min pi, whereas replacing $n-3$ PUFA by $n-6$ PUFA allowed a more pronounced decrease during the same interval. These results may be associated

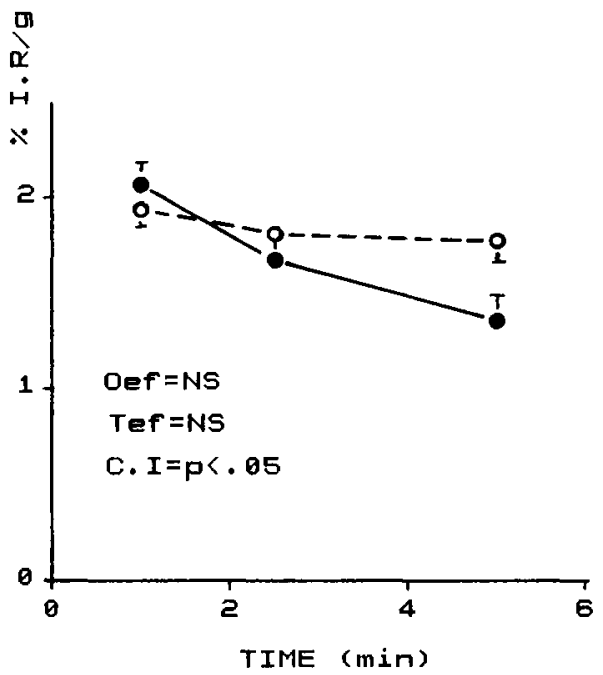

Fig 1. Effect of sunflower oil (filled circles) and linseed oil (open circles) feeding on timeevolution of total cardiac radioactivity (means \pm SEM). (\% IR/g: percentage of injected radioactivity per $\mathrm{g}$ fresh tissue; Oef $=$ oil effect; Tef $=$ time effect; $\mathrm{Cl}=$ cross interaction). The number of experiments is the same as in table III. with a difference in fatty acid metabolism. To further clarify these dietary-induced differences, a radioanalysis of myocardial hydrophobic and hydrophilic components was carried out during the first $5 \mathrm{~min}$ following $1-14 \mathrm{C}$ palmitate injection. Hydrophobic compounds contained free palmitate and its esterified forms (fig 2), whereas hydrophilic products resulted from palmitate oxidation and included radiolabelled acetyl CoA and Krebs cycle intermediates. The dietary-induced differences observed in total myocardial radioactivity may be related to the radiolabelling of hydrophobic components (fig 2a). The radioactivity decrease in the hydrophobic compounds was more pronounced in group $S$ than in group $L$. Since radiolabelled lipids cannot retrodiffuse in the extracellular space in the absence of albumin in the perfusion fluid (Spector et al, 1965), one might expect the larger decrease in radiolabelled lipids observed in group $S$ to be associated with a greater production of labelled hydrophilic compounds. However, this was not the case (fig 2b) since neither oil effect nor cross-interaction were found to be significant on the hydrophilic fraction. These observations suggest an accelerated betaoxidation and a higher oxidation of the hydrophilic components in the group $S$ hearts.

The time-evolution of radioactivity in each lipid class is presented in table IV. The radioactivity in free fatty acids decreased rapidly between 1 and $2.5 \mathrm{~min}$ pi and then plateaued until the fifth min pi, indicating a very rapid oxidation of the radiolabelled free fatty acids in water-soluble products or incorporation into complex lipids. The unexpectedly elevated plateau of radioactivity observed between 2.5 and 5 min pi could appear contradictory as compared to previous results reported by others using the non-working rat heart model (Cuchet et al, 1685). In such a model, the 


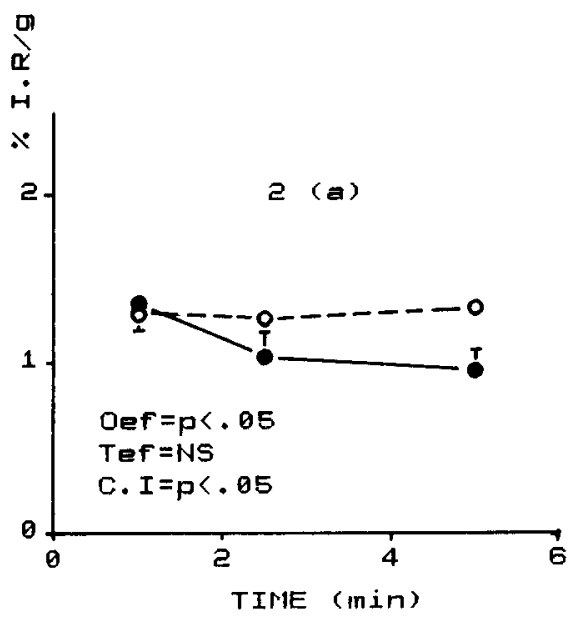

Table IV. Influence of dietary polyunsaturated fatty acids on the incorporation of radioactivity in lipid classes.

\begin{tabular}{|c|c|c|c|c|c|}
\hline Time pi & Group & D FFA & $D G$ & $T G$ & $P L$ \\
\hline \multirow{2}{*}{$1 \mathrm{~min}$} & $\underset{(n=5)}{S}$ & $\begin{array}{c}0.21 \\
\pm 0.014\end{array}$ & $\begin{array}{c}0.34 \\
\pm 0.039\end{array}$ & $\begin{array}{c}0.38 \\
\pm 0.030\end{array}$ & $\begin{array}{r}0.43 \\
\pm 0.023\end{array}$ \\
\hline & $\underset{(n=5)}{\mathrm{L}}$ & $\begin{array}{c}0.18 \\
\pm 0.015\end{array}$ & $\begin{array}{c}0.35 \\
\pm 0.020\end{array}$ & $\begin{array}{c}0.35 \\
\pm 0.033\end{array}$ & $\begin{array}{c}0.38 \\
\pm 0.053\end{array}$ \\
\hline \multirow{2}{*}{$2.5 \mathrm{~min}$} & $\underset{(n=4)}{S}$ & $\begin{array}{c}0.15 \\
\pm 0.014\end{array}$ & $\begin{array}{c}0.19 \\
\pm 0.026\end{array}$ & $\begin{array}{c}0.37 \\
\pm 0.026\end{array}$ & $\begin{array}{c}0.31 \\
\pm 0.026\end{array}$ \\
\hline & $\underset{(n=5)}{\mathrm{L}}$ & $\begin{array}{c}0.15 \\
\pm 0.010\end{array}$ & $\begin{array}{c}0.26 \\
\pm 0.019\end{array}$ & $\begin{array}{c}0.47 \\
\pm 0.057\end{array}$ & $\begin{array}{c}0.39 \\
\pm 0.035\end{array}$ \\
\hline \multirow{2}{*}{$5 \mathrm{~min}$} & $\underset{(n=5)}{S}$ & $\begin{array}{c}0.13 \\
\pm 0.019\end{array}$ & $\begin{array}{c}0.18 \\
\pm 0.033\end{array}$ & $\begin{array}{c}0.32 \\
\pm 0.078\end{array}$ & $\begin{array}{c}0.31 \\
\pm 0.031\end{array}$ \\
\hline & $\underset{(n=6)}{\mathrm{L}}$ & $\begin{array}{c}0.16 \\
\pm 0.014\end{array}$ & $\begin{array}{c}0.25 \\
\pm 0.022\end{array}$ & $\begin{array}{c}0.48 \\
\pm 0.072\end{array}$ & $\begin{array}{c}0.41 \\
\pm 0.024\end{array}$ \\
\hline ANOVA & $\begin{array}{l}\text { Oef } \\
\text { Tef } \\
\mathrm{Cl}\end{array}$ & $\begin{array}{c}N S \\
P<0.01 \\
N S\end{array}$ & $\begin{array}{c}N S \\
P<0.01 \\
\text { NS }\end{array}$ & $\begin{array}{c}\text { NS } \\
\text { NS } \\
P<0.05\end{array}$ & $\begin{array}{ll} & \text { NS } \\
& \text { NS } \\
5 & \text { NS }\end{array}$ \\
\hline
\end{tabular}

FFA: free fatty acids, DG: diglycerides; TG: triglycerides; PL: phospholipids. The results are expressed as $\%$ of injected radioactivity per $g$ (means \pm SEM). The ANOVA (analysis of variance) results refer to oil effect (Oef), time effect (Tef) and cross-interaction (Cl). NS = not significant.

\section{TIME (min)}

Fig 2. Time-evolution of radioactivity (means \pm SEM) in hydrophobic (a) and hydrophilic (b) fractions of the hearts of rats fed sunflower oil (filled circles) or linseed oil (open circles). (\% IR/ $\mathrm{g}$ : percentage of injected radioactivity per $\mathrm{g}$ fresh tissue; Oef = oil effet; Tef = time effect; $\mathrm{Cl}$ $=$ cross interaction). The number of experiments is the same as in table III.

labelled free fatty acids were rapidly metabolized and disappeared completely from the myocardium within the first $2 \mathrm{~min}$ pi. In the working heart model, the mainte-

nance of radioactivity in unesterified fatty acids might be related to the injection mode and could be due to extracellular fatty acid-albumin complexes bound to the atrial and ventricular walls. Diglycerides followed a time-evolution of radioactivity similar to that of free fatty acids, which indicates rapid diglyceride synthesis from ${ }^{1-14} \mathrm{C}$ palmitate and further transformation of the diglyceride fraction in triglycerides and phospholipids. Nevertheless, some radioactivity might be stored in the diglyceride fraction. No significant time effect was 
found for triglycerides and polar lipids. Thus, complex lipid synthesis occurred mainly during the first min pi and their hydrolysis did not occur throughout perfusion. Comparison of the data between the 2 dietary groups did not indicate any significant difference except for the time evolution in triglycerides. The incorporation of $1-{ }^{14} \mathrm{C}$ palmitate into the triglyceride fraction seemed to be prolonged and more important when rats were fed linseed oil.

\section{DISCUSSION}

The present study was aimed at determining the influence of membrane lipid environment on myocardial function and metabolism. For this purpose, 2 diets differing only in their fatty acid composition (C18:2 $n-6$ or $C 18: 3 n-3)$ were given to rats for a period of $8 \mathrm{wk}$. This resulted in an altered myocardial phospholipid fatty acid profile. Beare-Rogers and Nera (1976) also demonstrated that dietary linolenate-rich linseed oil provoked a decrease in C20:4 n-6 and $\mathrm{C} 22: 4 \mathrm{n}-6$, an increase in C22:5 $n-3$ and $C 22: 6 n-3$, and a reduction of the $n-6$ / $\mathrm{n}-3$ ratio in cardiac phospholipids. Thus, dietary linseed oil mimics the effect of fish oil on the fatty acid composition of membrane phospholipids (Hock et al, 1987). The decrease in $n-6 / n-3$ ratio in the membrane phospholipids did not induce any change in the cardiac mechanical work of isolated perfused hearts, as already reviewed (Lamers et al, 1987). Nevertheless, the spontaneous beating was slightly reduced and several metabolic parameters were modified: the oxidation of $1-14 \mathrm{C} \mathrm{pal}-$ mitate was decreased and its incorporation into triglycerides increased. The reason why a lowered $n-6 / n-3$ ratio induced a decreased cardiac rate in isolated perfused rat hearts remains unclear. An elevated preload pressure might be involved. The group L hearts could be less resistant to this mechanical stress. Beyond this mechanical hypothesis, the differences in cardiac rate may be due to metabolic events. The heart, in vivo as well as in perfusion, is composed of cardiomyocytes, local nervous cells, fibroblasts, endothelial cells, and circulating cells such as leukocytes (Keller et al, 1988). Such a pluricellularity implies a great number of metabolic controls of cardiac mechanical activity. Amongst the regulation systems, 2 could be of decisive importance in the determination of cardiac rate: i) 2- and/or 3-series prostaglandin production. A positive chronotropic effect of $\mathrm{PGI}_{2}$ and its stable analog fluoroprostacyclin has been demonstrated in spontaneously beating guinea pig atria (Fassina et al, 1983), and ii), catecholamine production and agonist release from nervous cells which is known to modulate cardiac rate. The magnitude of agonist release could differ with the nervous cell fatty acid profile and the receptor response could also be modulated by the lipid microenvironment of cardiomyocyte membranes (Hotfmann, 1986). The present study does not indicate which of these hypotheses is responsible for the observed changes in cardiac rate.

Although cardiac mechanical work did not seem to be affected by the diets, the oxidation of $1-14 \mathrm{C}$ palmitate by $n-6$ PUFArich hearts seemed to be accelerated as compared to that of $n-3$ hearts, resulting in a reduction of radiolabelled palmitate storage into triglycerides. Several hypotheses could explain the increased fatty acid oxidation observed in the $n-6$ hearts. First, increased biochemical work could result from the increased cardiac rate. More excitation-contraction-relaxation cycles without alteration of mechanical work intensity might accelerate the turnover of high energy phosphates, and increase oxygen consumption and substrate degradation. Un- 
fortunately, cardiac oxygen consumption was not determined in this study and it is not possible to confirm this hypothesis. On the other hand, if myocardial biochemical work was not increased in $n-6$ hearts, the increase in palmitate degradation could be due to several phenomena: i), decreased glucose transport because of the altered lipid environment, which could induce an increase in beta-oxidation; ii), a modification of the activity of the membrane-bound enzymes involved in fatty acid oxidation (acyl coA synthetase, acyl coA-carnitine transferase I, acyl carnitine-coA transferase II), resulting in a modulation of palmitate degradation. Further investigation appears necessary to clarify this point.

In conclusion, dietary polyunsaturated fatty acids are able to alter the contractile and metabolic functions of isolated working rat hearts by modifying the fatty acid composition of membrane phospholipids. Further experiments, including the determination of cardiac oxygen consumption and the evaluation of mitochondrial function would allow the effect of $n-6$ and $n-3$ PUFA on cardiac rate to be elucidated.

\section{ACKNOWLEDGMENTS}

The authors wish to thank S Almaza for her technical assistance and $D$ Cid for typing the manuscript.

\section{REFERENCES}

Beare-Rogers JL, Nera EA (1976) Nutritional effects of partially hydrogenated low erucic rapeseed oils. Lipids 12, 769-774

Bizerte C, Sezille G, Bertrand M, Jaillard J (1964) Chromatographie en couche mince des principales classes de lipides. Ann Biol Clin 22, 861-897
Bligh EG, Dyer WJ (1959) A rapid method of total lipid extraction and purification. Can J Biochem Physiol 37, 911-917

Cuchet P, Demaison L, Bontemps L, Keriel C, Mathieu JP, Pernin C, Marti-Battle D, Riche F, Vidal M, Comet M (1985) Do iodinated fatty acids undergo a non-specific deiodination in the myocardium. Eur J NuCl Med 10, 505510

Dagnelie P (1975) Théories et Méthodes Statistiques. Presses Agronomiques de Gembloux, Belgium, vol 2

Fassina G, Tessari F, Dorigo P (1983) Positive inotropic effect of a stable analogue of $P G I 2$ and $\mathrm{PGI} 2$ on isolated guinea pig atria. Pharmacol Res Commun 15, 735-749

Folch J, Lees M, Stoane-Stanley GH (1957) A simple method for the isolation and purification of total lipids from animal tissues. $J$ Biol Chem 226, 497-509

Grynberg A, Fantini E, Athias P, Degois M, Guenot $L$, Courtois $M$, Khatami $S$ (1988) Modification of the $n-6 / n-3$ fatty acid ratio in the phospholipids of rat ventricular myocytes in culture by the use of synthetic media: functional and biochemical consequences in normoxic and hypoxic conditions. $J$ Mol Cell Cardiol 20, 863-874

Hartog JM, Verdouw PD, Klompe M, Lamers JMJ (1987) Dietary mackerel oil in pigs: effects on plasma lipids, cardiac sarcolemmal phospholipids and cardiovascular parameters. J Nutr 117, 1371-1378

Hock CE, Holahan MA, Reibel DK (1987) Effect of dietary fish oil on myocardial ischemic damage. Am J Physiol 252, H554-H560

Hoffmann $P$ (1986) Cardiovascular actions of dietary polyunsaturates and related mechanisms. Prostaglandins Leukotrienes Med 21, 113-147

Juaneda P, Rocquelin G (1985) Rapid and convenient separation of phospholipids and nonphosphorus lipids from rat hearts using silica cartridges. Lipids 20, 40-41

Keller AM, Clancy RM, Barr ML, Marboe CC, Cannon PJ (1988) Acute reoxygenation injury in the isolated rat heart: role of resident cardiac mast cells. Circ Res 63, 1044-1052

Lamers JMJ, Hartog JM, Verdouw PD, Hulsmann W (1987) Dietary fatty acids and myo- 
cardial function. Basic Res Cardiol 82, 209-221

Nalbone G, Termine E, Leonardi J, Portugal H, Lechene $P$, Calaf $R$, Lafont $R$, Lafont $H$ (1988) Effect of dietary salmon oil feeding on rat heart lipid status. $J$ Nutr $118,809-817$

Neely JR, Leibermeister H, Battersby EJ, Morgan HE (1967) Effect of pressure development on oxygen consumption by isolated rat heart. Am J Physiol 212, 804-814

Rocquelin G, Yoyo N, Ducruet JM (1986) Influence des acides linoléique $(18: 2 n-6)$ et linol- énique (18:3n-3) sur la composition la permeabilité et la fluidité des phospholipides cardiaques du rat : étude à l'aide de modèles membranaires (liposomes). Reprod Nutr Dev 26, 97-112

Spector AA, Steinberg D, Tanaka A (1965) Uptake of free fatty acids by Ehrlich ascite tumor cells. J Biol Chem 240, 1032-1041

Swanson JE, Kinsella JE (1986) Dietary $n-3$ polyunsaturated fatty acids: modification of rat cardiac lipids and fatty acid composition. J Nutr 116, 514-523 